Available online at $\quad$ http://www.jfas.info

\title{
USING THE DETERMINISTIC FACTOR SYSTEMS IN THE ANALYSIS OF RETURN ON EQUITY
}

\author{
R. V. Nagumanova*, A. Sabirova \\ Kazan Federal University, Institute of Management, Economics and Finance,Kazan, 420008, \\ Russia
}

Published online: 08 August 2017

\begin{abstract}
The article contains theoretical reflections on the relevance of the analysis of the profitability of shareholders equity. Return on equity reflects the efficiency of the administrative apparatus of the Organization and is of particular value to assess the investment attractiveness of the organizations. This article provides deterministic multi-factor models, reflecting the influence of various factors on return on equity. When analyzing the profitability of equity is appropriate use of borrowed capital, because most organizations in its activities are also using the borrowed capital, which affects the amount of shareholders equity.In practice, when analyzing the effectiveness, return on equity should be compared with the value of bank interest on the deposit. If the ratio of net profits to its equity below or equal the profitability of bank deposits, the business of the organization is not efficient. The aim of this work is the analysis of models of calculation of profitability of shareholder equity and the selection of optimum and versatile methods of calculation. Application of quantitative and qualitative indicators in the analysis allows to evaluate the efficiency of use of own capital.
\end{abstract}

Key words: Return on equity, profitability analysis, cost-benefit analysis model of equity, equity, capital efficiency.

\section{INTRODUCTION}

Heads of organizations constantly have to take extraordinary decisions related to the financial management of the organization, its development and the State.

Author Correspondence, e-mail: author@gmail.com

doi: http://dx.doi.org/10.4314/jfas.v9i2s.65 
Most financial analysis managers spend based on profit, revenue. Indicators data is insufficient for most real and effective analysis should also count and other indicators of activity of the enterprise, its rise or decline. One of these indicators is return on equity. This indicator shows the effectiveness of any organization.

The return on equity is influenced by various factors, among which the main ones are used by the capital and profits of the organization received for the period. These factors also include return on sales, return on borrowed capital, the ratio of assets to equity, as well as asset turnover.

In modern scientific literature to date still have discussions associated with the interpretation and clarification of the formulas used in calculating return on equity. For example, RoucanKane, Filatov, Lizalova and Quijanouse different formulas to calculate the profitability of shareholders equity(Roucan-Kane M., et al., 2013), (Lizalovaand Kozakova,2013), (Quijano, 2013).

Financial analysis of the rich combination of different methods of calculation and analysis of this indicator, however, there is no generally accepted methodology for calculating profitability of shareholders equity, and the best model is not defined, which could reflect the influence of all factors on return on equity(FilatovandRudykh, 2014).

While researching this work uses by scientific and educational-methodical literature, articles in periodicals. Essence of concept capital considers KarimZ.A. (2013)иAdeleke A.I. (2012). Roucan-Kane M. (2013)

considersthe theoretical foundations of the concepts of return on equity.Skogsvik S. (2010) investigatesthe usefulness of analyzing the profitability of shareholders equity. LeotedeCarvalhoR. (2014) conducts risk analysis of attracting debt capital. TeodorH. (2014) in its article offers methods for analysis of profitability of shareholders equity. FilatovE.A. (2014)reveals the features of the model «Dupont».

Lizalova L. (2013)и Ng S.T. (2010)consider the influence of different characteristics on the profitability of own capital in various branches of economy articles. Discussion on the relationship between the quality of financial reporting and the cost of equity is expounded in the article Shevlin T. (2013).

Authors analyze the profitability of capital with some parties, however, did not offer a model analysis of return on equity, which would undertake an analysis of all the activities of the organization.Therefore, the objective of this study is to explore models of calculation of profitability of shareholders equity and to define best methodology for universal, given the impact of certain factors on the indicator. 
For this purpose, it is necessary to identify factors influencing the return on equity of the organization and consider the interaction of indicators based on the use of deterministic factor models.

\section{METHOD}

Own capital determines the value of the property owned by the organization. This is the net assets that characterize the share out of assets after deducting all its liabilities. This definition of equity involve principles of international financial reporting standards.

Return on equity is calculated by dividing the net profit on equity of the organization(RoucanKane and et al., 2013):

$\mathrm{ROE}=\frac{\mathrm{NP}}{\mathrm{E}},(1$.

ROE- return on equity; NP - net profit; E - equity.

The use of net income when calculating profitability of shareholders equity due to the fact that the source of replenishment of the shareholders equity is net earnings of the organization. If necessary, calculating return on equity for the period other than a year, the calculation produces the following formula (Karim Z.A., Zaidi M.A.S., Karim B.A. 2013). To do this, net profit is multiplied by the number of days in a year (365) and divide by the number of days in the period for which received the profit margin. The denominator used the average value of shareholders equity.

$\mathrm{ROE}=\mathrm{NP} * \frac{365 / \mathrm{Number} \text { of days in the period }}{(\mathrm{E} \text { beginning of period } \mathrm{E} \text { at the end of the period }) / 2}$,

In addition to the given formula in the analysis of the profitability of equity using multi-factor models. The first models of three and five factors were developed by DuPont. Consider a return on equity of the Organization as the result of the interaction of three factors: the level of net profit attributable to unit 1 product sold, the turnover rate of assets and leverage ratio (Skogsvik and Skogsvik, 2010):

$\mathrm{ROE}=\frac{\mathrm{NP}}{\mathrm{E}}=\frac{\mathrm{NP}}{\mathrm{E}} * \frac{\mathrm{R}}{\mathrm{R}} * \frac{\mathrm{A}}{\mathrm{A}}=\frac{\mathrm{NP}}{\mathrm{R}} * \frac{\mathrm{R}}{\mathrm{A}} * \frac{\mathrm{A}}{\mathrm{E}}=\mathrm{ROS} * \mathrm{AT} * \mathrm{FD}$, (3.)

ROE - return on equity; NP- net profit;E- the cost of equity capital;R- sales in the reporting period; A- total assets of the organization; ROS- return on sales in the reporting period;ATasset turnover ratio; FD- leverage ratio.

Growth of the organization, will be higher if there has been an increase in the level of net profit on 1 unit of sold products, growing asset turnover, and if the organization has formulated a greater amount of financial resources on 1 unit of own funds of the organization. 
In the model "Dupont"of the five factors in addition to those factors that were included in the previous model, earnings before tax is introduced (EBT)-indicator of the tax burden and the profit before tax and interest payments on loans and borrowings (EBIT)interest rate burden(Teodorand Maria, 2014).

$\mathrm{ROE}=\frac{\mathrm{NP}}{\mathrm{EBT}} * \frac{\mathrm{EBT}}{\mathrm{EBIT}} * \frac{\mathrm{EBIT}}{\mathrm{R}} * \frac{\mathrm{R}}{\mathrm{A}} * \frac{\mathrm{A}}{\mathrm{E}}=\mathrm{TB} * \mathrm{IB} * \mathrm{OM} * \mathrm{AT} * \mathrm{FD},(4$.

OM- operating margin.

Indicator of the tax burden in this model characterizes the Organization's tax burden on income tax. Growth of this indicator is due to the reduction of tax liabilities of the organization. The cost of borrowed funds in this model reflects the percentage burden. Growth of this indicator is possible due to the formation of the Organization of the credit portfolio, the average interest rate of which is minimal (Shevlin, 2013).

When analyzing the profitability of equity is appropriate use of borrowed capital, because most organizations in its activities, are also using the borrowed capital, which affects the amount of shareholders equity.

Consider the debt can be another way for this to three factor models "Dupont" add an indicator of loan capital, the formula represented below (Skogsvik and Skogsvik, 2010):

$\mathrm{ROE}=\frac{\mathrm{NP}}{\mathrm{E}}=\frac{\mathrm{NP}}{\mathrm{E}} * \frac{\mathrm{R}}{\mathrm{R}} * \frac{\mathrm{A}}{\mathrm{A}} * \frac{\mathrm{L}}{\mathrm{L}}=\frac{\mathrm{A}}{\mathrm{E}} * \frac{\mathrm{L}}{\mathrm{A}} * \frac{\mathrm{R}}{\mathrm{L}} * \frac{\mathrm{NP}}{\mathrm{R}},(5$.

L-the amount of borrowed capital of the organization; $\frac{L}{A}-$ the debt ratio of the organization, $\frac{\mathrm{R}}{\mathrm{L}}$ debt capital turnover; $\frac{\mathrm{NP}}{\mathrm{R}}$ - return on sales.

The return on equity is affected profitability of sales, asset turnover and financial sustainability. There are also basic factors that affect these indicators. To study in detail the impact of these indicators expand on their underlying factors.

$\mathrm{ROE}=\left(1-\frac{\mathrm{VC}+\mathrm{FC}+\mathrm{OC}}{\mathrm{V} * \mathrm{P}}\right) * \frac{\mathrm{V} * \mathrm{P}}{\mathrm{E}+\mathrm{L}} *\left(1+\frac{\mathrm{L}}{\mathrm{E}}\right),(6$.

VC- variable costs on production; FV- fixed costs; OC- other costs that are not included in the cost of production; $\mathrm{V}$ - volume of sales; $\mathrm{P}$ - the price at which products were sold.

Using this formula, can analyze how a change in one base factor influenced the final figure. For example, what result led the increase in production or services?

The above model can also lead to another mind, while the net profit can be decomposed as the difference between the revenue and product cost:

$\mathrm{ROE}=\frac{\mathrm{NP}}{\mathrm{E}}=\frac{\mathrm{R}-\mathrm{S}}{\mathrm{E}}=\frac{\mathrm{R}}{\mathrm{E}}-\frac{\mathrm{S}}{\mathrm{E}}=\mathrm{TRE}-\mathrm{SC},(7$.

$\mathrm{S}$ - cost of sales;TRE- turnover ratio shareholders equity; $\mathrm{SC}$ - share of the costs (full cost of sales) in equity. 
In the formula 7 can be factored into the cost of production rate of its expenses-material resources, labour costs and social payments, amortization, as well as other costs (the composition of production costs consider according to Russian standards PBU10/99 «Expenses of the organization»). As a result, we obtain the following model:

$\mathrm{ROE}=\frac{\mathrm{NP}}{\mathrm{E}}=\frac{\mathrm{R}}{\mathrm{E}}-\frac{\mathrm{M}}{\mathrm{E}}-\frac{\mathrm{Lab}}{\mathrm{E}}-\frac{\mathrm{A}}{\mathrm{E}}-\frac{\mathrm{OE}}{\mathrm{E}},(8$.

M- the material costs; Lab- labor costs; A - depreciation; OE- other costs.

When searching for untapped reserves of the Organization, particular importance attaches to the examination of such factors that determine indicators of material intensity, effort.

Combine all the above models into one holistic formula and obtain the following multi-factor deterministic model, which is presented in the formula 9 and 10. In this case, the model provided on seven factors that allow more detailed analysis of the activities of the organization. In the formula 9 and 10 in the first factor (profitability from sales by profit before tax) use the proceeds from the sales and cost of production.

$$
\begin{aligned}
& \mathrm{ROE}=\frac{\mathrm{R}-\mathrm{S}}{\mathrm{EBT}} * \frac{\mathrm{EBT}}{\mathrm{EBIT}} * \frac{\mathrm{EBIT}}{\mathrm{R}} * \frac{\mathrm{R}}{\mathrm{L}} * \frac{\mathrm{L}}{\mathrm{A}} * \frac{\mathrm{A}}{\mathrm{E}},(9 .) \\
& \mathrm{ROE}=\left(\frac{\mathrm{V} * \mathrm{P}}{\mathrm{EBT}}-\frac{\mathrm{VC}+\mathrm{FC}+\mathrm{OC}}{\mathrm{EBT}}\right) * \frac{\mathrm{EBT}}{\mathrm{EBIT}} * \frac{\mathrm{EBIT}}{\mathrm{R}} * \frac{\mathrm{R}}{\mathrm{L}} * \frac{\mathrm{L}}{\mathrm{A}} * \frac{\mathrm{A}}{\mathrm{E}},(10 .)
\end{aligned}
$$

\section{RESULT}

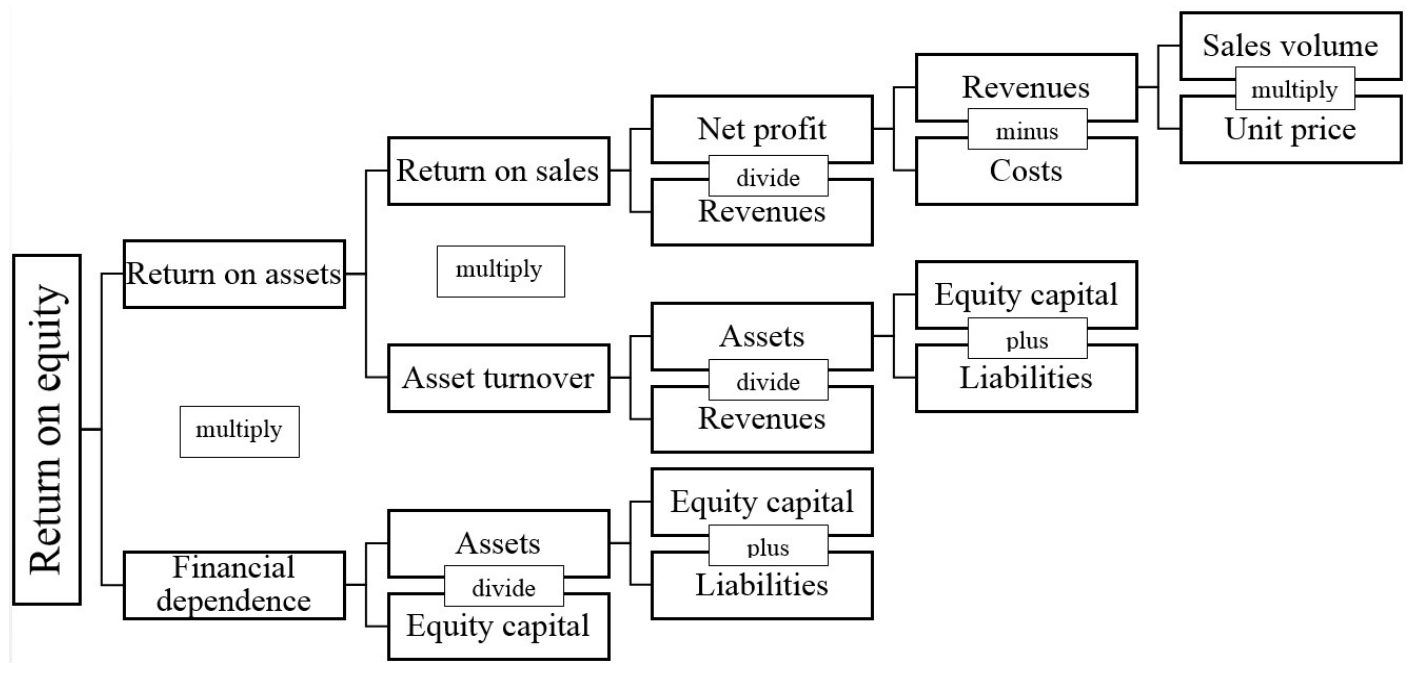

Fig.1. Diagram of the factor influencing the return on shareholders equity

Figure 1 shows the influence of factors on return on equity organization. In the diagram, represented the basic factors affecting this rate. This scheme is reflected in the formula 6 and is included in the formula 9 and 10. 
Table 1. Benefit analysis on equity using the seven-factor model

\begin{tabular}{|c|c|c|c|c|}
\hline Indicators & 2015 year & 2014 year & $\begin{array}{l}\text { Growth } \\
\text { (decrease) in } \\
\text { absolute terms }\end{array}$ & $\begin{array}{c}\text { Rates of } \\
\text { growth, } \\
\%\end{array}$ \\
\hline 1 & 2 & 3 & 4 & 5 \\
\hline Net profit, money unit & 205477 & 277599 & -72122 & 74,02 \\
\hline Revenues, money unit & 6936069 & 5486309 & 1449760 & 126,43 \\
\hline Sales volume, qt & 11600 & 10700 & 900 & 108,41 \\
\hline Unit price of product, money unit & 598 & 513 & 85 & 116,62 \\
\hline Cost of sales, money unit & 6984703 & 5444554 & 1540149 & 128,29 \\
\hline Total variable costs, money unit & 5856139 & 4630394 & 1225745 & 126,47 \\
\hline Fixed costs, money unit & 486320 & 486320 & 0 & 100,00 \\
\hline Other expenses, money unit & 642244 & 327840 & 314404 & 195,90 \\
\hline $\begin{array}{l}\text { The annual average cost of loan capital, } \\
\text { money unit }\end{array}$ & 3914624,5 & 3692370,5 & 222254 & 106,02 \\
\hline $\begin{array}{l}\text { The annual average cost of assets, money } \\
\text { unit }\end{array}$ & 4552179 & 4088387 & 463792 & 111,34 \\
\hline $\begin{array}{l}\text { The annual average cost of equity capital, } \\
\text { money unit }\end{array}$ & 637554,5 & 396016,5 & 241538 & 160,99 \\
\hline Earnings before taxes, money unit & 247634 & 355613 & -107979 & 69,64 \\
\hline $\begin{array}{l}\text { Earnings before interest and taxes, money } \\
\text { unit }\end{array}$ & 593610 & 675150 & -81540 & 87,92 \\
\hline $\begin{array}{l}\text { The share of revenues in earnings before } \\
\text { taxes }\end{array}$ & 28,01 & 15,43 & 12,58 & 181,55 \\
\hline $\begin{array}{l}\text { The share of product costs in earnings } \\
\text { before taxes: }\end{array}$ & 28,21 & 15,31 & 12,89 & 184,23 \\
\hline $\begin{array}{l}\text { The share of total variable costs in earnings } \\
\text { before taxes }\end{array}$ & 23,65 & 13,02 & 10,62 & 181,62 \\
\hline $\begin{array}{l}\text { The share of total fixed costs in earnings } \\
\text { before taxes }\end{array}$ & 1,96 & 1,37 & 0,59 & 143,60 \\
\hline $\begin{array}{l}\text { The share of other costs in the earnings } \\
\text { before taxes }\end{array}$ & 2,59 & 0,92 & 1,67 & 281,32 \\
\hline
\end{tabular}




\begin{tabular}{|l|c|c|c|c|}
$\begin{array}{l}\text { The share ofearnings before taxes in } \\
\text { earnings before interest and taxes (interest } \\
\text { burden) }\end{array}$ & 0,42 & 0,53 & $-0,11$ & 79,21 \\
\hline $\begin{array}{l}\text { The share of earnings before interest and } \\
\text { taxes in revenues(operating return on sales) }\end{array}$ & 0,09 & 0,12 & $-0,04$ & 69,54 \\
\hline Loan capital turnover ratio & 10,88 & 13,85 & $-2,97$ & 78,53 \\
\hline The tension coefficient & 0,86 & 0,90 & $-0,043$ & 95,22 \\
\hline Coefficient of financial dependence & 7,14 & 10,32 & $-3,1837$ & 69,16 \\
\hline Return on equity & 0,3223 & 0,701 & $-0,3787$ & 45,98 \\
\hline
\end{tabular}

Table2. Calculation of effect factors on return on equity when using seven-factor model

\begin{tabular}{|c|c|c|c|c|c|c|c|c|}
\hline \multirow[b]{2}{*}{ Substitution } & \multicolumn{7}{|c|}{ Factors } & \multirow{2}{*}{$\begin{array}{l}\text { The overall } \\
\text { result, (it.2- } \\
\text { it.3)*it. } 4 * \text { it. } 5 * \\
* \text { it. } 6 * \text { it. } 7 * \text { it. } 8\end{array}$} \\
\hline & $\begin{array}{c}\mathrm{NP} / \mathrm{EB} \\
\mathrm{T}\end{array}$ & $\begin{array}{c}\mathrm{S} / \mathrm{EB} \\
\mathrm{T}\end{array}$ & $\begin{array}{c}\text { EBT/EBI } \\
\mathrm{T}\end{array}$ & EBIT/R & $\mathrm{R} / \mathrm{L}$ & $\mathrm{L} / \mathrm{A}$ & $\mathrm{A} / \mathrm{E}$ & \\
\hline 1(it.) & 2 & 3 & 4 & 5 & 6 & 7 & 8 & 9 \\
\hline $\begin{array}{l}\text { Previous period, } \\
\left(\mathrm{Y}_{0}\right)\end{array}$ & 15,43 & 15,31 & 0,53 & 0,12 & $\begin{array}{c}13,8 \\
5\end{array}$ & 0,9 & $\begin{array}{l}10,3 \\
2\end{array}$ & 0,701 \\
\hline $\begin{array}{l}1 \text { substitution, } \\
\left(\mathrm{Y}_{1}\right)\end{array}$ & 28,01 & 15,31 & 0,53 & 0,12 & $\begin{array}{c}13,8 \\
5\end{array}$ & 0,9 & $\begin{array}{c}10,3 \\
2\end{array}$ & 106,35 \\
\hline $\begin{array}{l}2 \text { substitution, } \\
\left(\mathrm{Y}_{2}\right)\end{array}$ & 28,01 & 28,21 & 0,53 & 0,12 & $\begin{array}{c}13,8 \\
5\end{array}$ & 0,9 & $\begin{array}{c}10,3 \\
2\end{array}$ & $-1,645$ \\
\hline $\begin{array}{l}3 \text { substitution, } \\
\left(\mathrm{Y}_{3}\right)\end{array}$ & 28,01 & 28,21 & 0,42 & 0,12 & $\begin{array}{c}13,8 \\
5\end{array}$ & 0,9 & $\begin{array}{c}10,3 \\
2\end{array}$ & $-1,303$ \\
\hline $\begin{array}{l}4 \text { substitution, } \\
\left(\mathrm{Y}_{4}\right)\end{array}$ & 28,01 & 28,21 & 0,42 & 0,09 & $\begin{array}{c}13,8 \\
5\end{array}$ & 0,9 & $\begin{array}{c}10,3 \\
2\end{array}$ & $-0,906$ \\
\hline $\begin{array}{l}5 \text { substitution, } \\
\left(\mathrm{Y}_{5}\right)\end{array}$ & 28,01 & 28,21 & 0,42 & 0,09 & $\begin{array}{c}10,8 \\
8\end{array}$ & 0,9 & $\begin{array}{c}10,3 \\
2\end{array}$ & $-0,711$ \\
\hline $\begin{array}{l}6 \text { substitution, } \\
\left(\mathrm{Y}_{6}\right)\end{array}$ & 28,01 & 28,21 & 0,42 & 0,09 & $\begin{array}{c}10,8 \\
8\end{array}$ & 0,86 & $\begin{array}{c}10,3 \\
2\end{array}$ & $-0,677$ \\
\hline $\begin{array}{l}\text { Reporting period, } \\
\left(\mathrm{Y}_{7}\right)\end{array}$ & 28,01 & 28,21 & 0,42 & 0,09 & $\begin{array}{c}10,8 \\
8\end{array}$ & 0,86 & 7,14 & 0,323 \\
\hline
\end{tabular}


Table 1 presents an analysis of profitability of shareholders equity of the organization JSC "Tatojl Business". For the analysis used model by seven factors. In the table are calculated growth rate indicators.

Table 2 and table 3 shows the calculation of effect factors on return on equity when using seven-factor model. When calculating the used method lookup chain.

Table 3. The resultant influence factors on return on equity when using seven-factor model

\begin{tabular}{|c|l|r|}
\hline Influencing factors & $\begin{array}{l}\text { Calculation } \\
\text { formula }\end{array}$ & \multicolumn{2}{|l|}{ Meaning } \\
\hline $\mathrm{NP} / \mathrm{EBT}$ & $\mathrm{Y}_{1}-\mathrm{Y}_{0}$ & 105,652 \\
\hline $\mathrm{S} / \mathrm{EBT}$ & $\mathrm{Y}_{2}-\mathrm{Y}_{1}$ & $-107,998$ \\
\hline EBT/EBIT & $\mathrm{Y}_{3}-\mathrm{Y}_{2}$ & 0,342 \\
\hline EBIT/R & $\mathrm{Y}_{4}-\mathrm{Y}_{3}$ & 0,397 \\
\hline $\mathrm{R} / \mathrm{L}$ & $\mathrm{Y}_{5}-\mathrm{Y}_{4}$ & 0,195 \\
\hline $\mathrm{L} / \mathrm{A}$ & $\mathrm{Y}_{6}-\mathrm{Y}_{5}$ & 0,034 \\
\hline $\mathrm{A} / \mathrm{E}$ & $\mathrm{Y}_{7}-\mathrm{Y}_{6}$ & 1,001 \\
\hline The overall impact factors & & $-0,378$ \\
\hline
\end{tabular}

\section{DISCUSSION}

So far, the return on equity of the Organization remains an object of study by the scientists and economists. The attention to this indicator is because in addition to the efficiency of the use of equity shareholders equity reflects the ability of the organization to self-financing.

When calculating return on equity, the use of two indicators (net profit and shareholders equity), makes it impossible to analyze what factors influenced the change of the indicator. In this case, synergistic effect plays an important role(Lizalovaand Kozakova,2013).

A special approach to the calculation of profitability of equity is to use the Dupont formula (formula 3 and 4). The model "Dupont" enables organizations to carry out a detailed analysis. Unlike the three-factor model, the five-factor model shows the dependence of the profitability of equity from the impact of the financial and operational activities of the organization(Karim et al., 2013).

The majority of organizations in addition to its own funds often use borrowed capital in its activities. Use the extra capital allows the organization to expand the scope of its work, 
increase production, enter new markets, develop new types of product, as well as increase the quality and quantity of provided services organizations ( $\mathrm{Ng}$ et al., 2010).

In order to improve the return on equity of the organization have to borrow funds because the smaller size of the own funds of the organization leads to greater profitability. This is evidenced by financial leverage effect. Thus, the use of borrowed capital in calculating the return on equity will be justified (Amor-Tapia et al., 2010).

In practice, when analyzing the effectiveness, return on equity should be compared with the value of bank interest on the deposit. If the ratio of net profits to its equity below or equal the profitability of bank deposits, the business of the organization is not efficient.

Efficiency of use of own capital of the organization depends on the ratio of equity and debt capital, as well as the magnitude of profit organization. As a result, can achieve more if manage multiple factors(Leote de Carvalho et al., 2014).

Using formula 6 enables organizations to understand what direction you need to act to achieve a certain set of results. For example, will be more efficient to reduce costs and expenses of the organization or increase the price of products in order to achieve profitability growth equity, growth and organizational performance (Karim Z.A., Zaidi M.A.S., Karim B.A.,2013)

All of the above formulas combine formulas 9 and 10. Based on these formulas have conducted an analysis of the profitability of capital.

Based on the results of the calculations of return on equity of JSC "Tatojl business" in 2014 year decreased by $37.8 \%$. The greatest impact on return on equity has had a rate of return on sales. This figure has increased due to the increase of sales revenue due to higher sales volumes and higher prices. Other factors had a positive impact. The greatest impact was due to leverage ratio $100.1 \%$, it speaks about an increase in equity in capital structure of the organization.

The rising cost of production has had the most negative influence due to the growth of variable costs. This is reasonable because increased volume of production. However, despite the positive influence of all factors, return on equity decreased because during the reporting period, increased the cost of production. Therefore, organizations need to analyze the indicators of the cost of production organization, variable costs, and analyze whether this increased cost is fully justified(Quijano, 2013).

Seven-factor model more faithfully reflects the effectiveness of the organization's activities and allows you to analyze in detail the areas for further analysis, and that attention should be paid to in what direction should act to improve return on equity. These activities will help the organization to be more attractive to potential investors in the future (Adelekeand Gbadebo, 
2012).

\section{CONCLUSION}

In the analysis can be used deterministic factor models that allow you to analyze the influence of factors on return on equity. More qualitative and detailed analysis, with application of the deterministic factor models, allows the use of quantitative and qualitative indicators. This allows you to evaluate the effectiveness of using home equity to make informed management decisions in the organization's activities.

Accounting for the share of borrowed capital in balance currency in analysis on the equity of the organization allows to more examining the activities of the organization. This subsequently allows taking correct, effective strategic and tactical managerial decisions to streamline the activities of the organization.

Models listed in this article, in particular the model specified by the formula 9 and10, allow more deeply with the various parties to determine which change factors influence on the profitability of shareholders equity. It is worth noting that the factor analysis of profitability of shareholders equity is not limited to the models discussed in this article. To date, there are many other models-analogues, which also allow analyzing the effectiveness of financial and economic activities of the organization. The application of deterministic models gives you the ability to define new relationships, to formulate new indicators. This subsequently allows to expand reserves of increase of efficiency of use of own capital of the organization.

\section{REFERENCES}

1. Adeleke A.I., Gbadebo A.O. 2012. Macroeconomic policy and returns on equities: Empirical evidence from the Nigerian Capital Market// International Research Journal of Finance and Economics. Volume 83, pp. 106-119

2. Amor-Tapia B., Tascón M.T.,Fanluj J. L. 2010. Country creditor rights, information sharing, and commercial banks profitability // Finance aUver - Czech Journal of Economics and Finance. Volume 60, pp. 336-354

3. Filatov E.A., Rudykh L.G. 2014. Methods of functional factor analysis of financial profitability innovation company // Middle - East Journal of Scientific Research. Volume 21, pp. $97-102$

4. Karim Z.A., Zaidi M.A.S., Karim B.A. 2013. Monetary policy shocks, financial constraints and firm-level equity return: Panel evidence // JurnalPengurusan.Volume 39 
5. Leote de Carvalho R., Lu X., Moulin P. 2014. An integrated risk-budgeting approach for multi-strategy equity portfolios // Journal of Asset Management. Volume 15, pp. 24-47

6. Lizalova L., Kozakova P. 2013. Effect of the equity multiplier indicator in companies according to sectors // ActaUniversitatisAgriculturaeetSilviculturaeMendelianaeBrunensis. Volume 61, pp. 385-392

7. Ng S.T.,Xie J., Kumaraswamy M.M. 2010. Simulating the effect of risks on equity return for concession-based public-private partnership projects // Engineering, Construction and Architectural Management. Volume 17, pp. 352-368

8. Quijano M.2013. Consumption, change in expectations and equity returns // Applied Financial Economics. Volume 23, pp. 1839-1851

9. Roucan-Kane M., Wolfskill L.A., Boehlje M.D., Gray A.W. 2013. Bringing the DuPont profitability model to Extension // Journal of Extension. Volume 51

10. Shevlin T. 2013. Some personal observations on the debate on the link between financial reporting quality and the cost of equity capital// Australian Journal of Management.Volume 38, pp. 447-473

11. Skogsvik S., Skogsvik K. 2010. Accounting-based probabilistic prediction of ROE, the residual income valuation model and the assessment of mispricing in the Swedish Stock Market // Abacus. Volume 46, pp. 387-418

12. Teodor H., Maria A.T. 2014. The profit and loss account and the DuPont analysis Study models of performance in companies listed on BSE // WSEAS Transactions on Business and Economics. Volume 11, pp. 592-607

\section{How to cite this article:}

Nagumanova R V, Sabirova A. Using the deterministic factor systems in the analysis of return on equity. J. Fundam. Appl. Sci., 2017, 9(2S), 903-913. 